\title{
Helical Oligourea Foldamers as Powerful Hydrogen Bonding Catalysts for Enantioselective C-C Bond-Forming Reactions
}

Diane Bécart, ${ }^{\dagger, \ddagger}$ Vincent Diemer, ${ }^{\dagger, \|}$ Arnaud Salaün, ${ }^{\dagger}$ Mikel Oiarbide, ${ }^{*}$ Yella Reddy Nelli, ${ }^{\dagger}$ Brice Kauffmann, ${ }^{\S \odot}$ Lucile Fischer, ${ }^{\dagger}$ Claudio Palomo, ${ }^{*, *}$ and Gilles Guichard ${ }^{*}, \odot$

${ }^{\dagger}$ Univ. Bordeaux, CNRS, CBMN, UMR 5248, Institut Européen de Chimie et Biologie, 2 rue Robert Escarpit, F-33607 Pessac, France

‡Departamento de Química Orgánica I, Facultad de Químicas, Universidad del País Vasco UPV/EHU, Apdo. 1072, 20080 San Sebastián, Spain

${ }^{\S}$ Univ. Bordeaux, CNRS, INSERM, UMS3033/US001, Institut Européen de Chimie et Biologie, F-33607 Pessac, France

\section{Supporting Information}

ABSTRACT: Substantial progress has been made toward the development of metal-free catalysts of enantioselective transformations, yet the discovery of organic catalysts effective at low catalyst loadings remains a major challenge. Here we report a novel synergistic catalyst combination system consisting of a peptide-inspired chiral helical (thio)urea oligomer and a simple tertiary amine that is able to promote the Michael reaction between enolizable carbonyl compounds and nitroolefins with excellent enantioselectivities at exceptionally low (1/10000) chiral catalyst/ substrate molar ratios. In addition to high selectivity, which correlates strongly with helix folding, the system we report here is also highly amenable to optimization, as each of its components can be fine-tuned separately to increase reaction rates and/or selectivities. The predictability of the foldamer secondary structure coupled to the high level of control over the primary sequence results in a system with significant potential for future catalyst design.

\section{INTRODUCTION}

The ability to synthesize sequence-based non-natural oligomers that fold with high fidelity-foldamers-raises new prospects for mimicking biopolymers and for creating molecules with emergent functions tailored to various applications. ${ }^{1}$ The structure-guided design of foldamers that specifically recognize the surfaces of target biomacromolecules ${ }^{2}$ or interact with small molecular guests, ${ }^{3,4}$ as well as the fabrication of large architectures consisting of multiple secondary structure elements arranged in tertiary and quaternary structures, ${ }^{5,6}$ represent significant recent achievements in this direction. Bioinspired catalysis is another area in which foldamers have far-reaching potential, yet little progress has been made in this direction, despite the (theoretical) suitability of foldamers as biomimetic catalysts. For example, foldamer systems typically exhibit long-range conformational (e.g., helical) order, a property beyond the reach of small molecules and little explored in enantioselective catalysis.

Enzymes are generally regarded as highly efficient catalysts at low loading levels and commonly act through a mechanism involving multiple cooperative interactions. ${ }^{7}$ Likewise, preorganization of multifunctional catalysts through folding would be expected to contribute to enhanced catalysis efficiency through (i) cooperative substrate binding, (ii) specific stabilization of charged transition-states and intermediates, and (iii) minimization of the entropic cost of transition-state binding. ${ }^{8}$
Synthetic $\alpha$-peptides for example have received strong interest as bioinspired catalysts. ${ }^{9,10}$ In general, the active site consists of an array of reactive side chains preorganized in space through folding; ${ }^{9}$ more rarely, it involves main-chain functional groups. ${ }^{11}$ However-and in contrast to peptides which have gained a momentum as middle size catalysts for a number of stereo-, regio-, and chemoselective transformations ${ }^{9-13}-$ synthetic foldamers are yet to be fully explored as asymmetric catalysts. $^{14-19}$

Chiral aliphatic $\mathrm{N}, \mathrm{N}^{\prime}$-linked oligoureas ${ }^{20-23}$ are robust helical foldamers bearing structural resemblance to the $\alpha$-helical peptide backbone. Oligoureas typically mediate molecular recognition events through arrays of side chains displayed at the helix surface, ${ }^{24-26}$ yet the main chain itself is highly suited to bind small guest molecules. In particular, urea NHs at the positive end of the oligourea helix macrodipole have been shown to readily bind anions. ${ }^{27,28}$ The finding that anion binding occurs without helix unfolding suggested to us that oligourea foldamers could be useful in hydrogen bond catalysis. $^{29}$

Herein, enantiopure helical oligo(thio)urea foldamers have been investigated for the first time in the context of enantioselective carbon-carbon bond forming reactions. We

Received: June 5, 2017

Published: August 7, 2017 
provide evidence that short helically folded aliphatic $\mathrm{N}, \mathrm{N}^{\prime}$ linked oligoureas in combination with a simple achiral Brønsted base cocatalyst do work synergistically to promote the addition of carbonyl pronucleophiles to nitroalkenes with high reactivity and selectivity. A detailed structure-activity relationship study including a chain length dependence test ${ }^{30}$ demonstrated the strong correlation between the folding propensity of the oligomer (a property beyond the reach of small molecule catalysts) and its catalytic performance.

\section{RESULTS AND DISCUSSION}

Background, Working Hypothesis, and Design of Helical Oligo(thio)urea H-Bond Donor Catalysts. Hbond catalysis has become a major strategy for the activation of substrates in enantioselective organic reactions. ${ }^{31}$ Among the suitable H-bond donor groups, (thio)ureas have shown to be highly effective and versatile, either as discrete catalyst or as an integral part of a bifunctional Brønsted base-H-bond catalyst unit (Figure 1a, left). ${ }^{29,31-40}$ During the search for (thio)urea catalysts with improved activity and/or selectivity, the Smith laboratory discovered that thiourea catalysts featuring cooperative intramolecular $\mathrm{H}$-bonds were more effective than simple thioureas in Mukaiyama-Mannich reaction models (Figure 1b). ${ }^{8}$ The Pihko group further refined this concept and reported the design of tertiary amine/bis(thio)urea bifunctional catalysts with improved activity in Mannich reactions of malonates and ketoesters with imines. ${ }^{37,40}$ Also, Clayden has reported an internally organized bifunctional amine/thiourea catalyst that achieves remote asymmetric induction. ${ }^{19}$ In addition to the benefits resulting from preorganization of multifunctional catalysts through folding as noted above, it was suggested that the cooperative intramolecular H-bonding within the catalyst structure would (i) enhance the H-bonddonor ability of the thiourea group and (ii) liberate space around the thiourea moiety for effective substrate-catalyst coordination. Based on these precedents, and inspired by the way enzymes engage large networks of cooperative intramolecular H-bonds, we hypothesized that chiral (thio)urea catalysts capable of forming extended intramolecular $\mathrm{H}$ bonding networks, e.g. helical N,N'-linked oligoureas (Figure 1c), should present a unique catalytic profile.

At the outset, we decided to validate this idea in the context of a synergistic nucleophile/electrophile activation strategy ${ }^{41}$ (Figure 1a, right). Synergistic systems are highly modular and allow for an easier optimization of each catalyst component separately. Our second assumption was that while a relatively high concentration of (achiral) base may be required for the activation of the $\mathrm{C}-\mathrm{H}$ pronucleophile (to reach threshold concentration of the actual nucleophile), conversely relatively low amounts of the (chiral) $\mathrm{H}$-bond donor catalyst might suffice if, during the subsequent $\mathrm{C}-\mathrm{C}$ bond-forming (and stereochemistry-determining) step, a cooperative H-bond network with strong stereodirecting power operates.

In this work, we focused on 6-mer oligoureas which are known to adopt a well-defined helical conformation in both polar and nonpolar solvents. ${ }^{27,42}$ To differentiate the two sites available for substrate recognition and catalysis (Figure 1c), we increased the polarity and the polarizability of the first urea group by introducing a 3,5-bis(trifluoromethyl)phenyl group (oligomer 1a) and/or replacing the urea moiety by a thiourea (oligomer 2a) moiety (Figure 2). The primary structure (i.e., the sequence) of both oligomers is similar and consists of the repeat of three residues of $(S)$-configuration with different a Strategies for dual activation of nucleophile and electrophile

Bifunctional activation Synergistic activation

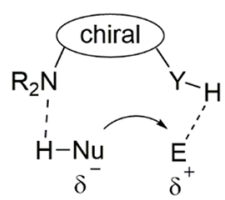

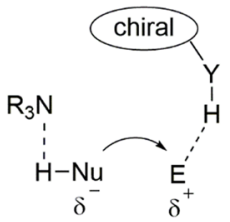

b Improving the catalytic profile of thiourea catalysts
Chiral H-bond small molecule catalyst preorganized through $\mathrm{H}$-bonding

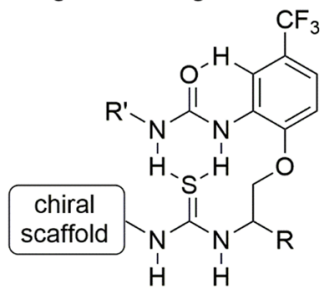

(Smith, 2009)
Bifunctional $\mathrm{H}$-bond small molecule catalyst preorganized through $\mathrm{H}$-bonding

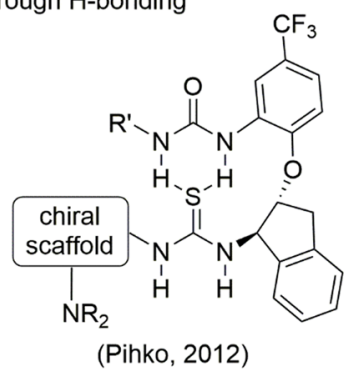

c This work

Helical foldamer catalyst with two distinct hydrogen bond donor sites

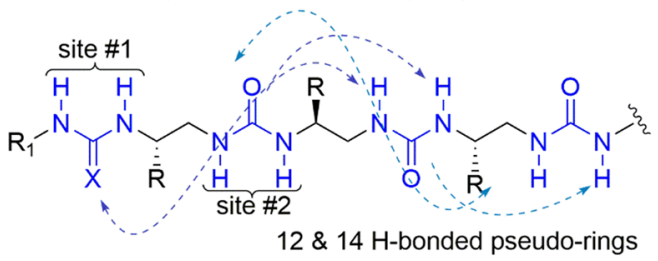

12 \& $14 \mathrm{H}$-bonded pseudo-rings

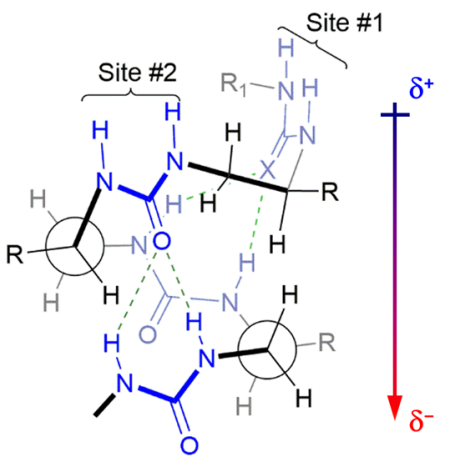

- Preorganization based on folding

- Two distinct recognition sites (different pKa depending on $\mathrm{R}^{1}$ )

- Controlled distance and orientation between sites \#1 \& \#2

- Contribution of the helix macrodipole

Figure 1. Rationale for the use of helical oligo(thio)urea foldamers as chiral components of binary catalytic systems. (a) Bifunctional and synergistic activation with H-bond donor catalysts; ${ }^{29,31-40}$ (b) di(thio)urea catalysts forming cooperative intramolecular $\mathrm{H}$-bonds; (c) representation of the extended chain of an $\mathrm{N}, \mathrm{N}^{\prime}$-linked oligourea and its folded behavior ${ }^{22,27}$ illustrating the two accessible H-bond donor sites near the positive pole of the helix macrodipole.

proteinogenic side chains $(\mathrm{Me}, i \mathrm{Pr}$, and $i \mathrm{Bu})$ to enable an unambiguous assignment of all backbone protons.

Crystals suitable for X-ray diffraction of both oligomers 1a and $\mathbf{2 a}$ were obtained, and the structures solved by direct methods in the $P 21$ and $P 1$ space groups, respectively. The crystal structures of 1a and 2a (Figure 2) which contain four and two independent molecules in the asymmetric units, 


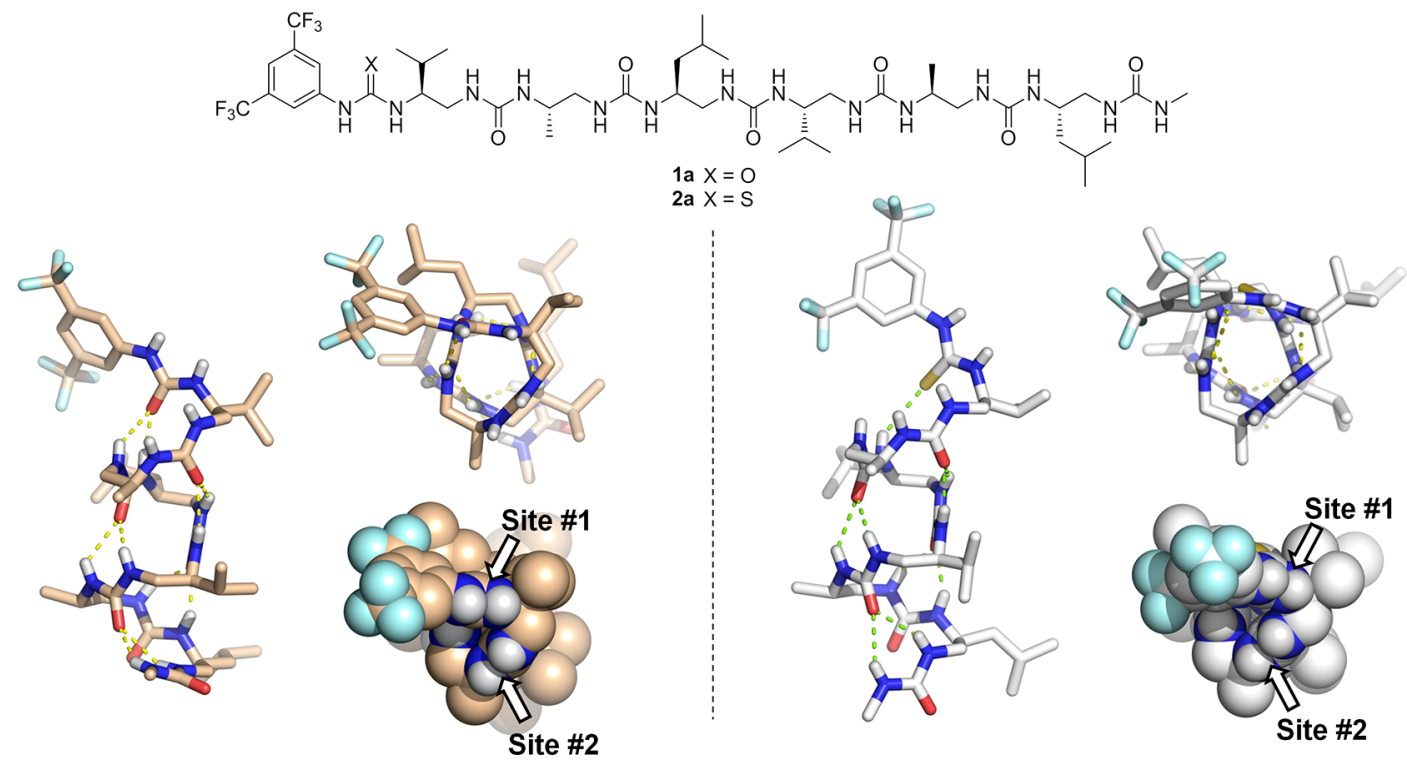

Figure 2. Foldamer-based chiral catalysts. Primary sequence of (thio)urea hexamers 1a and 2a and view along and down helical axis of their X-ray crystal structures showing accessibility of H-bond donor sites. The two helices are colored separately (1a, left and $\mathbf{2 a}$, right). The asymmetric units of 1a and 2a contain four and two independent molecules, respectively, of which only one is represented here (see supplementary Figure S1 for a structural alignment of all independent molecules in the asymmetric unit).

Table 1. Optimization of the Foldamer/Base Catalytic System and Structure-Activity Relationship Study ${ }^{a}$

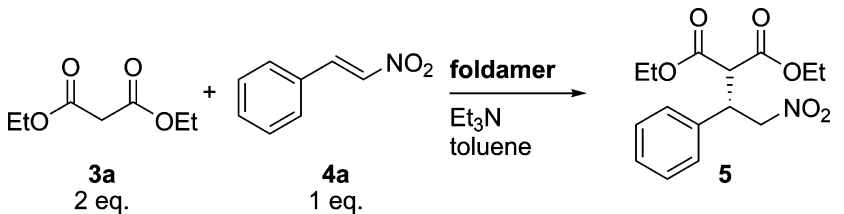

\begin{tabular}{|c|c|c|c|c|c|c|c|c|}
\hline entry & chiral catalyst & foldamer loading ( $\mathrm{mol} \%)$ & temp $\left({ }^{\circ} \mathrm{C}\right)$ & reaction time $(\mathrm{h})$ & $\mathrm{Et}_{3} \mathrm{~N}(\mathrm{~mol} \%)$ & conversion $(\%)$ & yield $(\%)$ & ee $(\%)$ \\
\hline 1 & - & - & -20 & 48 & 10 & 7 & n.d. & 0 \\
\hline 2 & 1a & 0.1 & -20 & $48(24)$ & 10 & $100(99)$ & $86(63)$ & $95(94)$ \\
\hline 3 & 1a & 0.05 & -20 & 48 & 10 & 100 & 85 & 94 \\
\hline 4 & 1a & 0.01 & -20 & 48 & 10 & 98 & 82 & 91 \\
\hline 5 & $1 a$ & 0.005 & -20 & 48 & 10 & 93 & 82 & 84 \\
\hline 6 & 1a & 0.001 & -20 & 48 & 10 & 67 & 49 & 74 \\
\hline 7 & $1 \mathrm{a}$ & 0.1 & -20 & 48 & 1 & 56 & 43 & 95 \\
\hline 8 & $1 \mathrm{a}$ & 0.1 & -20 & 48 & 5 & 100 & 85 & 95 \\
\hline 9 & 1a & 0.1 & -20 & 48 & 20 & 100 & 83 & 93 \\
\hline 10 & 1a & 0.1 & -20 & 16 & 30 & 100 & 78 & 93 \\
\hline 11 & $1 \mathrm{a}$ & 0.1 & rt & 48 & 10 & 98 & 75 & 89 \\
\hline 12 & $2 a$ & 0.1 & -20 & $48(24)$ & 10 & $98(94)$ & $80(59)$ & $93(88)$ \\
\hline 13 & $2 a$ & 0.1 & $\mathrm{rt}$ & 48 & 10 & 94 & 74 & 86 \\
\hline
\end{tabular}

${ }^{a}$ Reactions were performed with $0.5 \mathrm{mmol}$ of $\mathbf{4 a}$ and $1.0 \mathrm{mmol}$ of 3a. Yields correspond to isolated compound after chromatographic purification. The enantiomeric excess (ee) was determined by chiral HPLC analysis. Absolute configuration $(S)$ was assigned based on data from the literature.

respectively (see Supplementary Figure S1a,b), show that both oligomers have right-handed $(P)$ helicity with both carbonyl and/or thiocarbonyl groups of the first two (thio)urea units engaged in intramolecular H-bonding. As expected, ${ }^{42}$ the main differences between 1a and $2 \mathrm{a}$ reside in the geometry of the first intramolecular hydrogen bond between the terminal $\mathrm{C}=\mathrm{X}$ and the NHs of the third urea group (the $\mathrm{C}=\mathrm{X} \cdots \mathrm{N}$ distance increases from an average of $2.90 \AA$ in 1 a to a $3.42 \AA$ distance in 2a) that leads to a slight rearrangement of the first residue and of the 3,5-bis(trifluoromethyl)phenyl moiety.

A Synergistic Catalytic System at Low Chiral Catalyst/ Substrate Ratio. The conjugate addition ${ }^{43}$ of malonate ester (e.g., 3) to nitroalkenes (e.g., 4), ${ }^{44}$ was selected to assess the viability of the approach. This reaction is synthetically interesting due in part to the rich chemistry of the nitro group, ${ }^{45}$ and also because the resultant $\gamma$-nitro carbonyl adducts can be easily transformed into $\gamma$-amino acids, $\gamma$-butyrolactams, and pyrrolidines, all of which are interesting building blocks for pharmaceutical developments. ${ }^{46}$ Initial catalytic activities (addition of diethyl malonate $3 \mathbf{a}$ to nitrostyrene $4 \mathbf{a}$ ) were measured at different concentrations (from 1 to $0.00025 \mathrm{~mol}$ $\%$ ) of $1 \mathbf{a}$ ( or 2a) in nonpolar solvents in the presence of a fixed amount of a Brønsted base $\left(\mathrm{Et}_{3} \mathrm{~N}, 10 \mathrm{~mol} \%\right)$. Several interesting trends were observed from this first series of experiments (Table 1, entries 1-13, Supplementary Table 1 and Supplementary Figure 2a). 

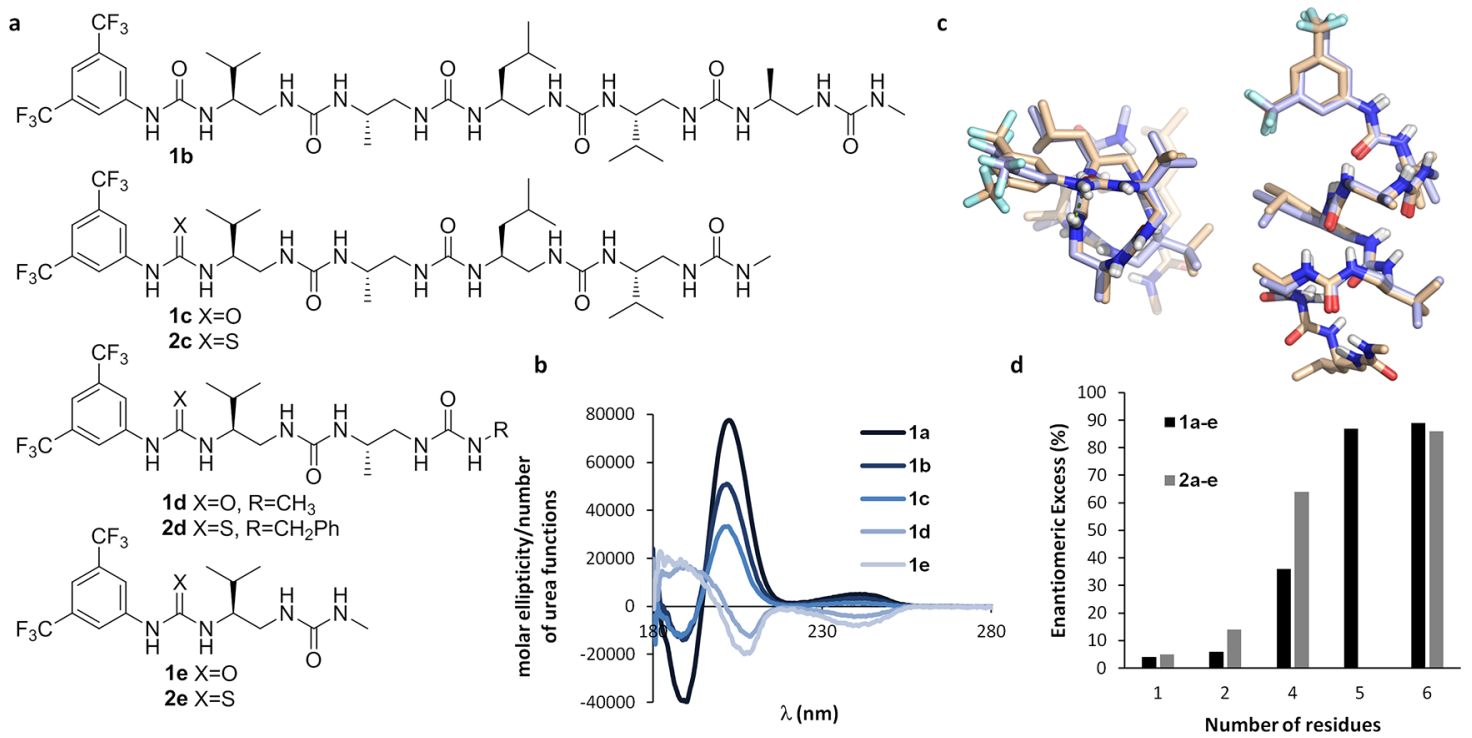

Figure 3. Catalysis and chain length dependence. (a) Primary sequence of analogues of 1a and $\mathbf{2 a}$ ranging in size from monomer to pentamer. (b) Electronic circular dichroism (ECD) analysis of oligoureas 1a-1e in trifluoroethanol. Molar residual ellipticity in deg. $\mathrm{cm}^{2} \cdot \mathrm{dmol}^{-1} \cdot \mathrm{residue}^{-1}$. (c) Structural alignment of the crystal structures of $\mathbf{1 a}$ (carbon atoms in sand) and $\mathbf{1 b}$ (carbon atoms in light blue). (d) Enantiomeric excess of the Michael adduct $\mathbf{5}$ determined by chiral HPLC analysis after purification for reactions conducted in the presence of $1 \mathbf{a}-\mathbf{e}$ and $\mathbf{2 a}-\mathbf{e}$. Reactions were performed at $\mathrm{rt}$ for $24 \mathrm{~h}$, with $0.1 \mathrm{~mol} \%$ catalyst, $10 \mathrm{~mol}^{2} \mathrm{Et}_{3} \mathrm{~N}$, on $0.67 \mathrm{mmol} \mathrm{scale}$.

The combination of $1 \mathrm{a}(0.1 \mathrm{~mol} \%)$ and $\mathrm{Et}_{3} \mathrm{~N}(10 \mathrm{~mol} \%)$ in toluene at $-20{ }^{\circ} \mathrm{C}$ was found to provide complete conversion and excellent enantioselectivities $\left(95 \% \mathrm{ee}^{47}\right)$, thus denoting that separate Brønsted base and chiral $\mathrm{H}$-bond donor work synergistically (Table 1, entry 2 and Supplementary Table 1, entry 1). ${ }^{48}$ There was almost no conversion in the absence of 1a $\left(\mathrm{Et}_{3} \mathrm{~N}\right.$ alone, entry 1$)$.

Remarkably, the reactivity and selectivity of the catalytic system $\left(1 \mathrm{a} / \mathrm{Et}_{3} \mathrm{~N}\right)$ remained largely unaffected when the chiral catalyst/substrate ratio was decreased to levels as low as 1:10 000 (Table 1, entries 2-4 and Supplementary Figure 2a). When as little as $0.01 \mathrm{~mol} \%$ of 1 a was employed, the Michael adduct 5 was still obtained in a yield of $82 \%$ with $91 \%$ ee (Table 1, entry 4). Note that just $0.05 \mathrm{mg}$ of $1 \mathrm{a}(0.01 \mathrm{~mol} \%)$ is needed in this case to convert $0.5 \mathrm{mmol}$ of nitrostyrene, whereas a similar conversion with a common small molecule bifunctional catalyst would typically require $>20 \mathrm{mg}$ (10 mol $\%)$ of catalyst. As initially hypothesized, the catalytic process requires a relatively high concentration of base relative to the chiral catalyst, as the reaction rate is significantly impacted at 1 mol \% of $\mathrm{Et}_{3} \mathrm{~N}$ (Table 1, entries 7 and 8). Conversely, increasing the concentration of $\mathrm{Et}_{3} \mathrm{~N}$ to 20 and $30 \mathrm{~mol} \%$ is well tolerated and allows shorter reaction times (Table 1, entries 9 and 10). The reaction with $1 \mathrm{a} / \mathrm{Et}_{3} \mathrm{~N}$ was slightly less selective at rt ( $89 \%$ ee, entry 11). The synthetic utility of $\mathbf{1 a}$ was further demonstrated by performing the reaction on a larger scale. Gram quantities of the Michael adduct ( $0.95 \mathrm{~g}$ after purification) and excellent ee (95\% ee) were obtained when the reaction was conducted on a $3.3 \mathrm{mmol}$ scale with $3.4 \mathrm{mg}$ of 1a $(0.1 \mathrm{~mol} \%)$.

Hexamer 2a, which contains a thiourea at the first position, also performed well but was systematically less effective than 1a for the addition of malonate $\mathbf{3 a}$ to the nitroolefin $\mathbf{4 a}$ (Table 1, entry 12 vs entry 2 (at $24 \mathrm{~h}$ ) and entry 13 vs entry 11 (at rt)), suggesting a subtle interplay of acidity ${ }^{49}$ and conformation in controlling the catalytic efficiency of the system. One plausible explanation is that the benefit of increasing the acidity by replacing the oxygen of the first urea by a sulfur atom may be counterbalanced by unfavorable conformational change and dynamics at the positive pole of the helix where catalysis takes place. $^{42}$

Catalysis upon Folding: Chain-Length Dependence and Temperature Effects. To investigate whether the helical conformation of oligo(thio)ureas $\mathbf{1 a}$ and $\mathbf{2 a}$ is critical to achieve rate acceleration and enantioselectivities reported in Table 1, we next prepared two series of shorter analogues $(\mathbf{1 b}-\mathbf{e}$ and $2 \mathrm{c}-\mathrm{e})$ ranging from 1 to 5 monomeric $\left(\mathrm{NHCH}(\mathrm{R})-\mathrm{CH}_{2}-\right.$ $\mathrm{NHCO}$ ) units, and sharing the same terminal bis(thio)urea segment and 3,5-bis(trifluoromethyl)phenyl moiety (Figure $3 a)$. Whereas analogues consisting of one (1e and $2 \mathbf{e}$ ) and two (1d and 2d) monomeric units are too short to adopt a helical conformation, longer analogues are expected to gradually populate the 2.5-helical conformation in nonpolar and moderately polar solvents. ${ }^{50}$ The helix dipole is also expected to increase with the length of the helix, possibly suggesting a more pronounced interaction of longer oligomers with charged intermediates during the catalytic process. To gain more specific information about the helix forming propensity of oligoureas $1 \mathbf{a}-\mathbf{e}$, we recorded their electronic circular dichroism (ECD) spectra in trifluoroethanol (Figure 3b). As expected, the tetramer (1c), pentamer (1b), and hexamer (1a), but not dimer $\mathbf{1 d}$ and monomer 1e, displayed the characteristic ECD signature of $(P)$-2.5-helical oligoureas, with a positive maximum at $\sim 203 \mathrm{~nm}$ whose intensity (mean residue ellipticity) increases with the number of residues in the chain. This observation was further supported by the degree of anisochronicity of NMR signals arising from diastereotopic protons in the chiral units of 1a-1e (Supplementary Table S2). We obtained an X-ray crystal structure of 5-mer $\mathbf{1 b}$. This oligomer is fully helical in the crystal, and an overlay with the structure of 1a (Figure 3c) by fitting the first five pairs of carbonyl $\mathrm{C}$ atoms indicates a very close match between the two helices including at the active site (root-mean-square deviation $(\mathrm{RMSD})=0.150 \AA$ ). 
All foldamers were then tested for their ability to catalyze the reaction between diethylmalonate $\mathbf{3 a}$ with nitrostyrene $\mathbf{4 a}$ at low chiral catalyst loading using conditions reported in Table 1 , entry 11 (chiral catalyst $0.1 \mathrm{~mol}^{\%}, \mathrm{Et}_{3} \mathrm{~N} 10 \mathrm{~mol} \%, \mathrm{rt}, 48 \mathrm{~h}$ ). A strong chain length dependence effect was observed (Figure $3 \mathrm{~d}$ and Supplementary Table S3) with almost no enantiocontrol in the presence of monomers (1e and $\mathbf{2 e}$ ) and dimers (1d and 2d) and the highest reactivity (94-98\% conversion) and selectivity ( $86-89 \%$ ee) for helically folded 5- and 6-mers (1a > $\mathbf{1 b}>2 \mathrm{a})$. Intermediate selectivities $(36-63 \%$ ee) were obtained with partially folded 4-mers, and in this case, conversion and stereocontrol were significantly higher with the thiourea containing derivative $2 \mathrm{c}$, suggesting that increased acidity of the catalyst could compensate for the limited conformational control. Overall these results support the view that a welldefined helical conformation is required for efficient stereocontrol in the catalytic process, and furthermore that even relatively short helices (e.g., 5-mer 1b) display an excellent catalytic activity profile at low oligomer/substrate ratio. Because the 2.5-helix of oligoureas is robust and shows significant thermal stability in nonpolar and moderately polar solvents, ${ }^{51}$ we decided to evaluate to which extent the activity of the catalytic system $1 \mathrm{a} / \mathrm{Et}_{3} \mathrm{~N}$ persists at high temperature. Although the selectivity gradually decreased between -20 and $80{ }^{\circ} \mathrm{C}$ the reactivity was not significantly affected, with the reaction at 80 ${ }^{\circ} \mathrm{C}$ still producing the Michael adduct in a satisfactory yield of $78 \%$ and $69 \%$ ee. This indicates that the active site as well as supramolecular interactions are largely maintained over a wide temperature range (Supplementary Figure S2b).

Scope of the Reaction and Fine-Tuning of the Selectivity. We next addressed the substrate scope of the reactions catalyzed by oligourea 1a by applying it to other 1,3dicarbonyl compounds and to a variety of nitroalkenes (Tables 2 and 3). The effectiveness of the catalyzed addition of malonate esters to nitrostyrene, in terms of reactivity and selectivity, inversely correlates with the size of the ester group, with dimethyl malonate $\mathbf{3} \mathbf{b}$ giving the fastest conversion and a remarkable $97 \%$ ee and tert-butyl malonate $3 \mathbf{e}$ being the least reactive (Supplementary Table S4, entries 1-5). When using cyclic ketoester 6 as a nucleophile, the resulting adduct 9 bearing a stereogenic quaternary center was formed with a high $98 \%$ ee and complete diastereoselectivity (Table 2, entry 1). As noted above, a distinctive feature of this synergistic approach as compared to the bifunctional catalyst approach is that variation of each catalyst component can be performed independently of the other. Thus, catalyst optimization may be simply achieved by modifying the nature of the associated Brønsted base. For example, during the initial scope of Michael donors, we observed that the reaction of acetylacetone 7 with nitrostyrene 4a to produce adduct 10a (Table 2, entry 2 ) proceeded with a low $63 \%$ ee under our established conditions. However, the reaction outcome could be significantly improved by employing trialkylamine bases with increasing alkyl chain length or bulkiness. Although we do not yet have a full explanation for this result, the data in Table 2 show that, among the bases tested, $i \operatorname{Pr}_{2} \mathrm{EtN}$ (DIPEA) gave the best enantioselectivity for the addition reactions with acetylacetone 7 and 1,3-diphenylpropane-1,3-dione 8 with ee's between 83 and >99\% (Table 2, entries $6,9,12$, and 15 ).

As shown in Table 3 , the catalyzed reaction of dimethyl malonate $3 \mathbf{b}$ with an array of nitroalkenes $\mathbf{4}$ was found to be quite independent of the electronic properties of the aryl ring of the nitroalkene. Compound $\mathbf{4 a}$ as well as nitroalkenes with
Table 2. Suitability of Several 1,3-Dicarbonyl Compounds as Nucleophiles and Influence of the Nature of the Amine Base Cocatalyst $^{a}$

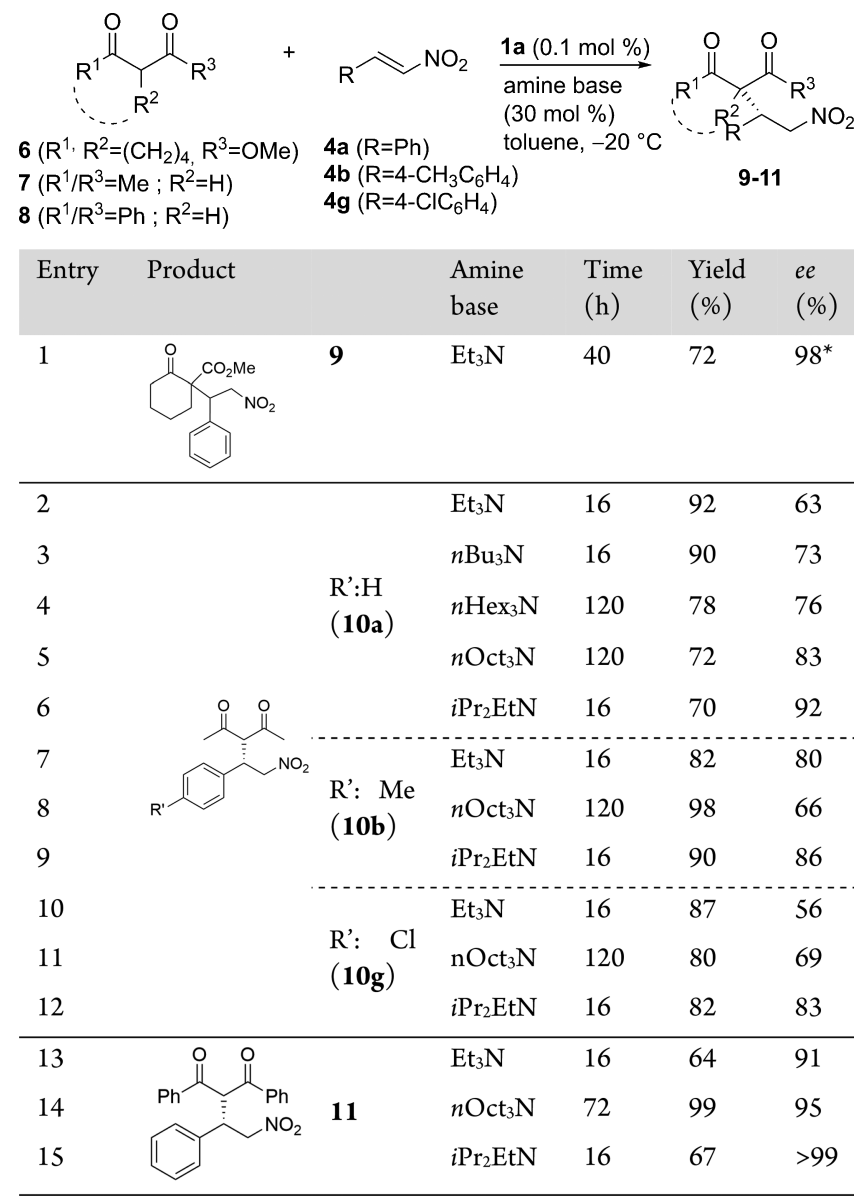

${ }^{a}$ Reactions were performed on $1 \mathrm{mmol}$ scale with 2 equiv of 1,3dicarbonyl compound. Yields correspond to isolated compound after chromatographic purification. The ee was determined by chiral HPLC analysis. Absolute configuration $(R)$ or $(S)$ was known or assigned by analogy. ${ }^{*}$ means $\mathrm{dr}(2 R / 2 S)=0: 100$.

electron donating $\beta$-aryl groups such as $\mathbf{4 b}, \mathbf{4 c}, \mathbf{4 d}$, and $4 \mathbf{e}$ led to the corresponding adducts $12 \mathbf{a}-\mathbf{e}$ with excellent chemical and stereochemical results, regardless of their $o$-, $m$-, or $p$ substitution pattern. Likewise, nitroalkenes $\mathbf{4 f}, \mathbf{4 g}$, and $\mathbf{4 h}$ with inductively electron-withdrawing fluoro, chloro, and bromo groups afforded Michael adducts $\mathbf{1 2 f}-\mathbf{h}$ with good yields and ee's up to $92 \%$. Somewhat inferior results were observed for the reaction of $4 \mathbf{i}$ and $4 \mathbf{j}$, bearing electron-poor $\beta$-aryl groups, which provided adducts $12 \mathrm{i}$ and $\mathbf{1 2} \mathbf{j}$ with $62 \%$ ee and $86 \%$ ee, respectively. In these cases, the enantioselectivity was largely improved by using DIPEA as a base (96\% and $93 \%$ ee, respectively) instead of $\mathrm{Et}_{3} \mathrm{~N}$. Nitroalkenes with heteroaromatic $\beta$-substituents such as $\mathbf{4 k}$ and $\mathbf{4 l}$ are also good acceptors and provide the corresponding adducts $12 \mathrm{k}$ and 121 in $98 \%$ ee and $97 \%$ ee, respectively. Conjugated nitroalkenes $4 m-4 p$ led to the respective adducts $12 \mathrm{~m}-\mathbf{p}$, although long reaction times were required. Again, the combination of DIPEA with 1a proved superior to the use of $\mathrm{Et}_{3} \mathrm{~N}$ in terms of stereocontrol (e.g., 12n-12p). Importantly, only a $0.1 \mathrm{~mol} \%$ catalyst loading was needed in the majority of the cases in order to achieve good yields of isolated product and high enantioselectivities. To the best of our knowledge, this represents the lowest catalyst/ 
Table 3. Scope of the Enantioselective Conjugate Addition of Dimethylmalonate to Nitroalkenes Catalyzed by $1 \mathrm{a}^{a}$

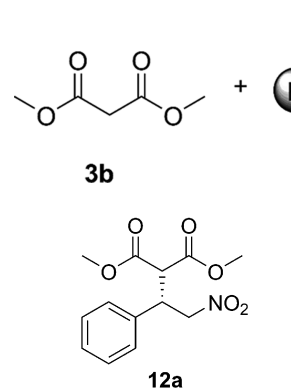

$16 \mathrm{~h}, 78 \%, 97 \%$ ee $(S)$

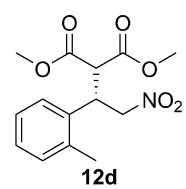

$16 \mathrm{~h}, 71 \%, 97 \%$ ee $(S)$

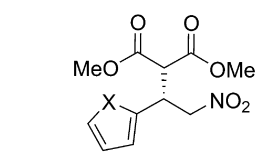

$\mathrm{X}=\mathrm{O} \mathbf{1 2 k} 16 \mathrm{~h}, 96 \%, 98 \%$ ee $(R)$ $\mathrm{X}=\mathrm{S} 12 \mathrm{I} 16 \mathrm{~h}, 96 \%, 97 \%$ ee $(R)$

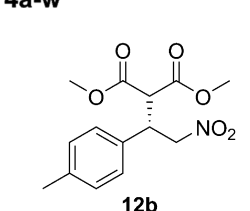

$16 \mathrm{~h}, 84 \%, 95 \%$ ee $(S)$

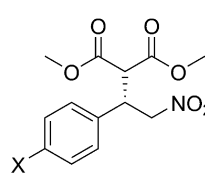

X
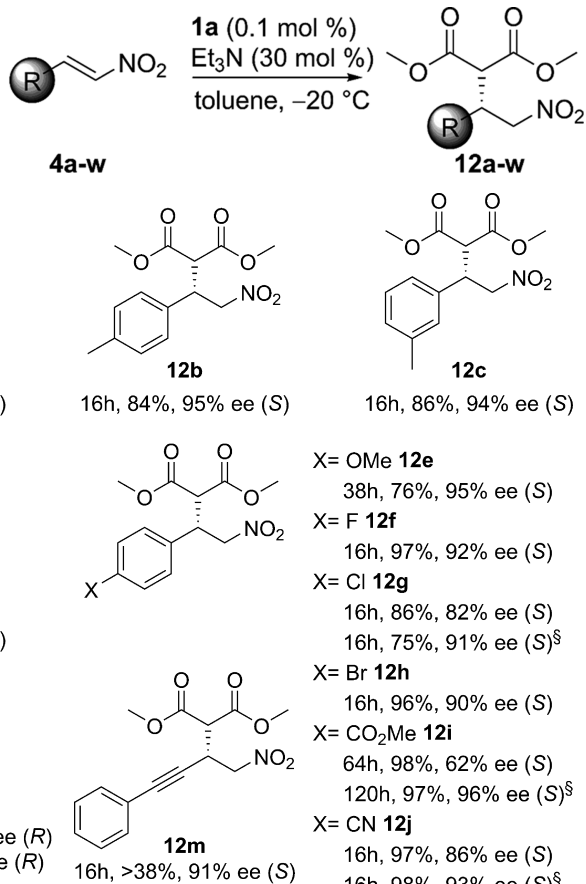

$16 \mathrm{~h}, 86 \%, 94 \%$ ee $(S)$

$\mathrm{X}=\mathrm{OMe} 12 \mathrm{e}$

$38 \mathrm{~h}, 76 \%, 95 \%$ ee $(S)$

$X=F 12 f$

$16 \mathrm{~h}, 97 \%, 92 \%$ ee $(S)$

$\mathrm{X}=\mathrm{Cl} \mathbf{1 2} \mathbf{g}$

$16 \mathrm{~h}, 86 \%, 82 \%$ ee $(S)$

$16 \mathrm{~h}, 75 \%, 91 \%$ ee $(S)^{\S}$

$X=\operatorname{Br} \mathbf{1 2 h}$

$16 \mathrm{~h}, 96 \%, 90 \%$ ee $(S)$

$x=\mathrm{CO}_{2} \mathrm{Me} \mathrm{12i}$

$64 \mathrm{~h}, 98 \%, 62 \%$ ee $(S)$

$120 \mathrm{~h}, 97 \%, 96 \%$ ee $(S)^{\S}$

$\mathrm{X}=\mathrm{CN} \mathbf{1 2} \mathbf{j}$

$16 \mathrm{~h}, 97 \%, 86 \%$ ee $(S)$

$16 \mathrm{~h}, 98 \%, 93 \%$ ee $(S)^{\S}$
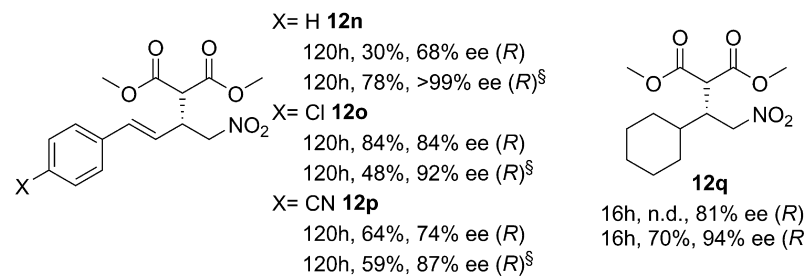

$16 \mathrm{~h}$, n.d., $81 \%$ ee $(R)$ $16 \mathrm{~h}, 70 \%, 94 \%$ ee $(R)^{\star}$

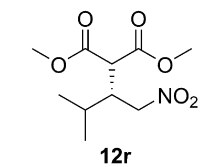

16h, n.d., $81 \%$ ee $(R)$

$16 \mathrm{~h}, 62 \%, 91 \%$ ee $(R)^{*}$

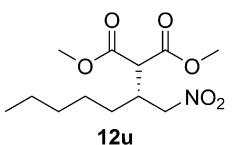

$12 \mathrm{u}$

$16 \mathrm{~h}, 70 \%, 92 \%$ ee $(R)^{\star}$

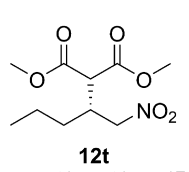

$16 \mathrm{~h}, 53 \%, 92 \%$ ee $(R)^{*}$

$16 \mathrm{~h}, 75 \%, 88 \%$ ee $(R)^{*}$

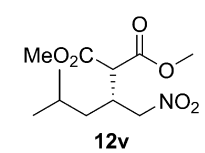

$16 \mathrm{~h}, 74 \%, 94 \%$ ee $(R)^{*}$ $16 \mathrm{~h}, 70 \%, 96 \%$ ee $(R)^{\S}$

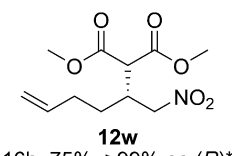

$16 \mathrm{~h}, 75 \%,>99 \%$ ee $(R)^{*}$

${ }^{a}$ Reactions were performed on $0.5 \mathrm{mmol}$ scale with 2 equiv of $\mathbf{3 b}$. Yields correspond to isolated compound after chromatographic purification and are given in percent. The ee was determined by chiral HPLC analysis. Absolute configuration $(R)$ or $(S)$ was known or assigned by analogy. ${ }^{\S}$ signifies the reaction was performed using DIPEA as base $(30 \mathrm{~mol} \%)$; $*$ means the reaction was conducted at $-30{ }^{\circ} \mathrm{C}$ using $0.3 \mathrm{~mol} \%$ catalyst.

substrate ratio employed in the Brønsted base catalyzed Michael reaction of malonate esters to nitroalkenes. ${ }^{33,52,53}$ Most significantly, the recalcitrant $\beta$-alkyl nitroalkenes such as $\mathbf{4 q}$ and $\mathbf{4 r}$, which generally lead to sluggish reactions and poor ee's, ${ }^{34,35}$ provided the corresponding adducts with ee's up to $81 \%$ at a $0.1 \mathrm{~mol} \%$ catalyst loading and $-20{ }^{\circ} \mathrm{C}$. In these cases, the enantioselectivity could be substantially improved by increasing the amount of catalyst to $0.3 \mathrm{~mol} \%$ and decreasing the reaction temperature to $-30{ }^{\circ} \mathrm{C}$. As shown in Table 3, extension to nitroalkenes $4 \mathbf{s}-\mathbf{w}$ with short, large, and ramified

$\beta$-alkyl chains is equally tolerated and provided adducts $12 s-\mathbf{w}$ in good yields and high ee's.

Structure-Reactivity/Enantioselectivity Relationship and Mechanistic Studies. We conducted analysis by ${ }^{1} \mathrm{H}$ NMR in toluene- $\mathrm{d}_{8}$ of mixtures of $1 \mathrm{a}, \mathrm{Et}_{3} \mathrm{~N}, 3 \mathrm{a}$, and $\mathbf{4 a}$ in order to generate information concerning the kinetics of the foldamer-catalyzed addition reaction of malonate to nitroolefin (Supplementary Figure S3). Using the method of flooding with $[3 \mathbf{a}]=10 \times[\mathbf{4 a}]$, we confirm that the reaction exhibits a firstorder kinetics with respect to nitrostyrene. The method of initial rates was used to determine the order in foldamer, base, and malonate $3 a{ }^{54}$ We found that the reaction is first-order with respect to base and malonate $\mathbf{3 a}$ and also exhibit a firstorder dependence in the foldamer at concentrations below $\sim 0.2 \mathrm{~mol} \%$.

The deviations from first-order kinetics at higher concentrations of 1 a could be rationalized by a possible aggregation of the foldamer, an explanation which is also supported by the small but substantial nonlinear effect which is observed at 0.1 mol \% when the ee of the catalyst is varied by mixing $\mathbf{1}$ and its enantiomer ent-1 in defined proportions (Supplementary Figure S4).

We next introduced sequence variations into $\mathbf{1 a}$ and $\mathbf{2 a}$ in order to interrogate the role of the first two (thio) urea moieties and gain additional insight into the principles governing the catalytic activity of oligoureas as a means to improve next generation foldamer-based catalysts (Figure 4). Pyrrolidine units in compounds $\mathbf{1 3 - 1 5}$ were used to selectively block the first or second accessible urea groups. The crystal structures of 15 (Figure 4b) and of the Boc-protected precursor of 14 (compound 20, Supplementary Figure S1c) show that the geometry of the 2.5-helix is compatible with the introduction of a pyrrolidine unit. In the crystal, the $\mathrm{CO}-\mathrm{N}-\mathrm{C} \beta-\mathrm{C} \alpha$ angle $(\phi)$ of the pyrrolidine units adopts a value $\left(\approx-96^{\circ}\right)$ close to that of standard residues in helical oligoureas and the carbonyl group of the pyrrolidine unit is engaged in typical H-bonds with urea NHs of canonical residues. Helix formation is also supported in solution by anisochronicities measured in the chiral units of compounds 13-15, although with some local perturbation at the site of the pyrrolidine insertion (Figure 4c). Despite the overall structural similarity between $14 / 15$ and $1 \mathrm{a} /$ 2a respectively, we found that the pyrrolidine residues in $\mathbf{1 4}$ and $\mathbf{1 5}$ were detrimental to the catalytic activity $(\approx 35 \%$ and $15 \%$ conversion, respectively) supporting a key role of the second urea site in catalysis (Table 4, entries 2 and 3).

The combination of oligourea 13 and $\mathrm{Et}_{3} \mathrm{~N}$ was more active, providing the Michael adduct in a moderate yield and $57 \%$ ee (Table 4, entry 1) which suggests that the replacement of the first chiral residue with a pyrrolidine unit is less critical to catalytic activity. The role of the first urea group in the catalytic process was further investigated by decreasing its acidic strength through replacement of the 3,5-bis(trifluoromethyl)phenyl termination with a 4-Br-phenyl group. This modification (16) leads to a similar outcome as to the pyrrolidine ring insertion at the first urea position (13), with a moderate yield and $68 \%$ ee (Table 4, entry 4). These data support a cooperative role of both ureas in the catalytic process.

We next probed the contribution of the stereocenter of the first chiral residue on the catalytic process by either removing the branched side chain (17 and 18) or replacing it with a benzyl group (19). The combination of two potentially destabilizing elements at the end of the helix, i.e. a flexible achiral 1,2-diaminoethyl residue ${ }^{55}$ and a thiourea termination ${ }^{42}$ 
a

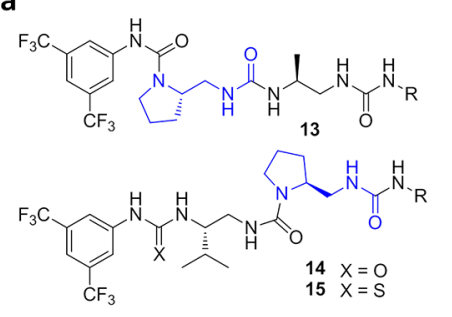

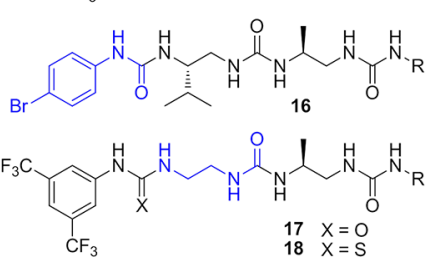<smiles>CC(CNC(=O)Nc1ccccc1)NCC(Cc1ccccc1)NC(=O)Nc1cc(C(F)(F)F)cc(C(F)(F)F)c1</smiles>

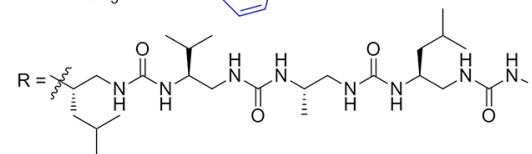

b
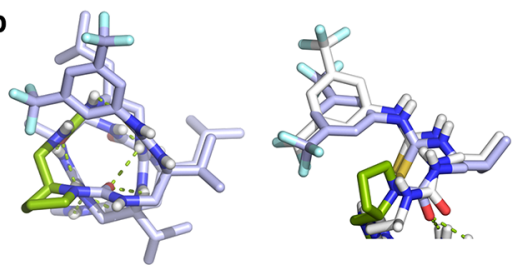

C
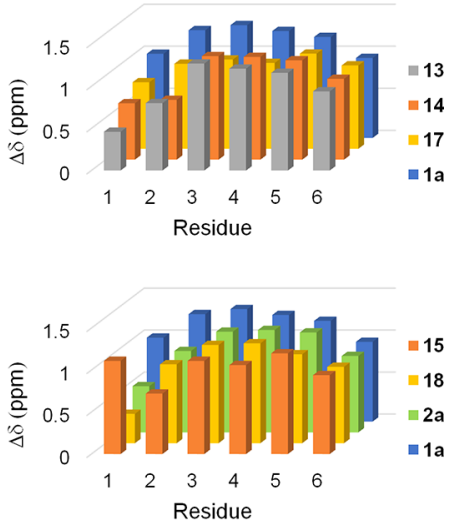

Figure 4. Oligomer sequences for structure-reactivity/enantioselectivity relationship study. (a) Analogues of 1a and 2a bearing various sequence variations at the first two positions: pyrrolidine residue replacements (13-15), terminal aromatic group modification (16), achiral 1,2-diaminoethyl residue replacement $(17,18)$, and benzyl side chain replacement (19). (b) Crystal structure of compound 15 with a pyrrolidine residue at the second position viewed down helix axis and superimposition with the structure of $2 \mathrm{a}$ ( $\mathrm{RMSD}=0.460 \AA$ \&y fitting the seven pairs of (thio) carbonyl C atoms). The pyrrolidine residue is colored in green. (c) Anisochronicity in the residues of catalysts 13-15 and 17-18 compared to that of catalysts 1a and 2a. The values have been measured in $\mathrm{CD}_{3} \mathrm{OH}$ for all compounds except 17 for which NMR analysis was conducted in DMSO- $d_{6}$.

Table 4. Correlation of the Foldamer Structure with the Catalytic Activity ${ }^{a}$

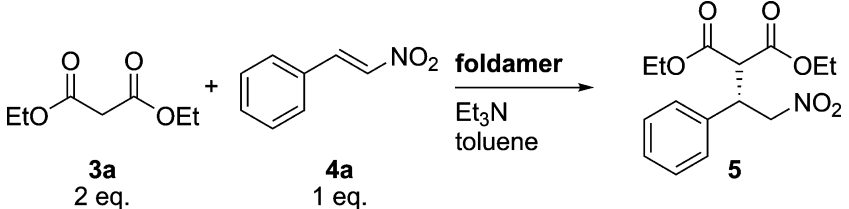

\begin{tabular}{|c|c|c|c|c|c|c|c|c|}
\hline entry & chiral catalyst & foldamer loading (mol \%) & temp $\left({ }^{\circ} \mathrm{C}\right)$ & reaction time $(\mathrm{h})$ & $\mathrm{Et}_{3} \mathrm{~N}(\mathrm{~mol} \%)$ & conversion (\%) & yield (\%) & ee $(\%)$ \\
\hline 1 & 13 & 0.1 & -20 & 48 & 10 & 72 & 47 & 57 \\
\hline 2 & 14 & 0.1 & -20 & 48 & 10 & 35 & 29 & 5 \\
\hline 3 & 15 & 0.1 & -20 & 48 & 10 & 15 & n.d. & 15 \\
\hline 4 & 16 & 0.1 & -20 & 48 & 10 & 62 & 48 & 68 \\
\hline 5 & 17 & 0.1 & -20 & 48 & 10 & 92 & 75 & 83 \\
\hline 6 & 18 & 0.1 & -20 & 48 & 10 & 45 & 40 & 35 \\
\hline 7 & 19 & 0.1 & -20 & 48 & 10 & 94 & 75 & 88 \\
\hline
\end{tabular}

${ }^{a}$ Reactions were performed with $0.5 \mathrm{mmol}$ of $\mathbf{4 a}$ and $1.0 \mathrm{mmol}$ of 3a. Yields correspond to isolated compound after chromatographic purification. The enantiomeric excess (ee) was determined by chiral HPLC analysis. Absolute configuration $(S)$ was assigned based on data from the literature.

(Figure 4a) in 18, was deleterious for the catalytic efficiency and resulted in poor conversion and stereocontrol (Table 4, entry 6). Interestingly, oligourea 17 , which has a urea termination, still produces the Michael adduct in good yield and selectivity $(83 \%$ ee $)$, providing evidence that the stereochemical outcome of the reaction largely depends on the helical nature of the catalyst and is not significantly controlled locally by the first chiral unit (Table 4, entry 5). In line with this result, catalyst $\mathbf{1 9}$ was found to behave similarly to 1a but with a slightly lower degree of stereocontrol (Table 4, entry7).

\section{CONCLUSIONS}

We report here the first successful development of customizable foldamers-aliphatic N,N'-linked oligoureas-as critical chiral components of synergistic catalytic systems (achiral base/ chiral $\mathrm{H}$-bond donor foldamer catalyst) for enabling efficient simultaneous activation of the nucleophile and electrophile at extremely low catalyst/substrate molar ratios. As little as 0.01 mol \% of foldamer $1 \mathrm{a}$ in combination with $10 \mathrm{~mol}^{\%} \mathrm{Et}_{3} \mathrm{~N}$ was shown to be sufficient to catalyze the addition of 1,3-dicarbonyl substrates to nitroalkenes in high yield and enantioselectivity.
This system is highly robust and, crucially, enables facile optimization, due to the separation of the base and $\mathrm{H}$-bond donor components of the catalyst system. For example, the use of DIPEA (instead of $\mathrm{Et}_{3} \mathrm{~N}$ ) in combination with 1a was subsequently found to substantially increase enantioselectivity in the most difficult cases. Other modular binary systems albeit nonchiral, such as a simple (thio)urea and a base component, have proven particularly versatile in macromolecular catalysis for ring opening polymerization of lactide. ${ }^{52,56}$ Furthermore, we gained insight into the mechanisms and origins of the high selectivity observed by varying the chiral catalyst primary sequence, folding propensity, and by introducing urea $\rightarrow$ thiourea replacements. This structure/activity relationship study revealed a strong correlation between the oligomer catalyst efficiency and its folding propensity in apolar and moderately polar solvents. It also supports a key role for the first two (thio)ureas close to the positive pole of the helix macrodipole, which is reminiscent of the role of amide NHs at the positive pole ( $\mathrm{N}$-terminus) of the helical polyleucine catalyst used in the Juliá-Colonna epoxidation. ${ }^{11,5}$

The chiral oligourea foldamers studied here combine a number of unique and positive features-such as synthetic 
accessibility, functional capability, sequence modularity, and high folding fidelity-which could be further applied to catalysis of other $\mathrm{C}-\mathrm{C}$ bond forming reactions, or even turned into distinct practical and scalable technologies. Overall the present development provides new insights into the factors that govern catalysis of organic reactions by middle size molecules and thus constitutes a new step toward approaching the efficiency of enzymes.

\section{METHODS}

General Procedure for the Synthesis of Oligo(thio)ureas. Oligomers 1, 2, and 13-19 and ent-1 were synthesized in solution using a stepwise approach and $\mathrm{N}-\mathrm{Boc}$ protected succinimidyl carbamate building blocks following previously reported procedures. ${ }^{27,55}$ Full details of chemical synthesis and purification can be found in the Supporting Information.

Hexamer 1a. Trifluoroacetic acid $(2 \mathrm{~mL})$ was added to a solution of the corresponding Boc-protected oligourea hexamer $(800 \mathrm{mg}, 0.88$ $\mathrm{mmol})$ in dichloromethane $(2 \mathrm{~mL})$, and the reaction mixture was stirred at room temperature for $4 \mathrm{~h}$. After completion of the reaction, trifluoroacetic acid and dichloromethane were evaporated under reduced pressure. DIPEA $(0.48 \mathrm{~mL}, 2.72 \mathrm{mmol})$ and 3,5-bis(trifluoromethyl)phenyl isocyanate $(0.24 \mathrm{~mL}, 1.36 \mathrm{mmol})$ were successively added to the resulting TFA salt dissolved in DMF $(4 \mathrm{~mL})$. The reaction mixture was stirred at room temperature for $16 \mathrm{~h}$. A sodium bicarbonate solution $(30 \mathrm{~mL})$ was added which led to gel formation which was recovered after filtration, then dissolved in methanol, concentrated, and dried under high vacuum. The recovered orange solid was triturated in acetonitrile to lead to the titled oligourea $\mathbf{1 a}$ as a white solid $(731 \mathrm{mg}, 81 \%) .{ }^{1} \mathrm{H}$ NMR $\left(400 \mathrm{MHz}, \mathrm{CD}_{3} \mathrm{OH}\right) \delta(\mathrm{ppm})$ $9.01(\mathrm{~s}, 1 \mathrm{H}), 8.00(\mathrm{brs}, 2 \mathrm{H}), 7.52(\mathrm{brs}, 1 \mathrm{H}), 6.56(\mathrm{dd}, J=10.2$ and 2.7 $\mathrm{Hz}, 1 \mathrm{H}), 6.50(\mathrm{dd}, J=9.8$ and $2.3 \mathrm{~Hz}, 1 \mathrm{H}), 6.37-6.45(\mathrm{~m}, 2 \mathrm{H}), 6.26$ $(\mathrm{d}, J=10.7 \mathrm{~Hz}, 1 \mathrm{H}), 6.24(\mathrm{~d}, J=10.3 \mathrm{~Hz}, 1 \mathrm{H}), 6.21(\mathrm{q}, J=4.9 \mathrm{~Hz}$, $1 \mathrm{H}), 6.03-6.11(\mathrm{~m}, 2 \mathrm{H}), 6.00(\mathrm{dd}, J=9.6$ and $3.6 \mathrm{~Hz}, 1 \mathrm{H}), 5.97(\mathrm{~d}, J$ $=10.6 \mathrm{~Hz}, 1 \mathrm{H}), 5.93(\mathrm{~d}, J=10.6 \mathrm{~Hz}, 1 \mathrm{H}), 5.86(\mathrm{~d}, J=10.1 \mathrm{~Hz}, 1 \mathrm{H})$, $4.00-4.15(\mathrm{~m}, 1 \mathrm{H}), 3.75-4.00(\mathrm{~m}, 4 \mathrm{H}), 3.48-3.75(\mathrm{~m}, 7 \mathrm{H}), 2.70(\mathrm{~d}, J$ $=4.8 \mathrm{~Hz}, 3 \mathrm{H}), 2.57-2.74(\mathrm{~m}, 2 \mathrm{H}), 2.24-2.47(\mathrm{~m}, 4 \mathrm{H}), 1.64-1.85(\mathrm{~m}$ $3 \mathrm{H}), 1.49-1.64(\mathrm{~m}, 1 \mathrm{H}), 1.12-1.32(\mathrm{~m}, 4 \mathrm{H}), 1.00-1.06(\mathrm{~m}, 9 \mathrm{H})$, $0.98(\mathrm{~d}, J=7.0 \mathrm{~Hz}, 3 \mathrm{H}), 0.88-0.95(\mathrm{~m}, 15 \mathrm{H}), 0.86(\mathrm{~d}, J=7.0 \mathrm{~Hz}$ $3 \mathrm{H}) ;{ }^{13} \mathrm{C}$ NMR $\left(100 \mathrm{MHz}, \mathrm{CD}_{3} \mathrm{OH}\right) \delta(\mathrm{ppm}) 162.1$ (C), $162.0(\mathrm{C})$, 161.8 (C), 161.6 (C), 161.4 (C), 160.9 (C), 158.2 (C), 143.2 (C), $133.1(\mathrm{q}, J=33 \mathrm{~Hz}, 2 \times \mathrm{C}), 124.6(\mathrm{q}, J=270 \mathrm{~Hz}, 2 \times \mathrm{C}), 118.8-$ $119.1(\mathrm{~m}, 2 \times \mathrm{CH}), 115.5-115.8(\mathrm{~m}, \mathrm{CH}), 56.7(\mathrm{CH}), 56.2(\mathrm{CH})$, $49.4(\mathrm{CH}), 49.1(\mathrm{CH}), 48.2\left(2 \times \mathrm{CH}_{2}\right), 47.3\left(\mathrm{CH}_{2}\right), 46.8(\mathrm{CH}), 46.3$ $\left(\mathrm{CH}_{2}\right), 46.1(\mathrm{CH}), 44.7\left(\mathrm{CH}_{2}\right), 44.4\left(\mathrm{CH}_{2}\right), 43.8\left(\mathrm{CH}_{2}\right), 42.7\left(\mathrm{CH}_{2}\right)$, $31.91(\mathrm{CH}), 31.88(\mathrm{CH}), 26.8\left(\mathrm{CH}_{3}\right), 26.1(\mathrm{CH}), 25.8(\mathrm{CH}), 23.6$ $\left(\mathrm{CH}_{3}\right), 23.5\left(\mathrm{CH}_{3}\right), 22.7\left(\mathrm{CH}_{3}\right), 22.4\left(\mathrm{CH}_{3}\right), 20.1\left(\mathrm{CH}_{3}\right), 20.0\left(\mathrm{CH}_{3}\right)$, $18.7\left(\mathrm{CH}_{3}\right), 18.5\left(\mathrm{CH}_{3}\right), 18.3\left(\mathrm{CH}_{3}\right), 18.2\left(\mathrm{CH}_{3}\right) ;{ }^{19} \mathrm{~F}$ NMR $(376$ $\mathrm{MHz}, \mathrm{CD} 3 \mathrm{OH}) \delta(\mathrm{ppm})-64.6 \mathrm{ppm}$; HRMS $\left(\mathrm{ES}^{+}, \mathrm{MeOH}\right)$ : calcd for $\mathrm{C}_{44} \mathrm{H}_{76} \mathrm{~F}_{6} \mathrm{~N}_{14} \mathrm{O}_{7}, 1027.59984$; found, 1027.60173.

General Procedure for the Catalytic Enantioselective Conjugate Addition of Dimethyl Malonate to Nitroalkenes (Table 3). To a vial charged with $1 \mathrm{a}(0.51 \mathrm{mg}, 0.5 \mu \mathrm{mol})$ were added the nitroalkene $(0.5 \mathrm{mmol})$ and a solution of freshly distilled dimethyl malonate $(0.11 \mathrm{~mL}, 1.0 \mathrm{mmol})$ in dry toluene $(0.5 \mathrm{~mL})$. The reaction mixture was cooled down to $-20{ }^{\circ} \mathrm{C}$, and tertiary amine $(0.15 \mathrm{mmol})$ was added. After complete consumption of the nitroalkene, the reaction mixture was quenched with $1 \mathrm{~N}$ hydrochloric acid solution, extracted three times with dichloromethane, washed with brine, dried over magnesium sulfate, filtered, and concentrated. The crude material was purified on silica gel chromatography as described in the Supporting Information. The enantiomeric excess was determined by chiral HPLC as described in the Supporting Information.

Circular Dichroism. ECD experiments were performed on a Jasco J-815 spectrometer. Measurements on oligoureas $1 \mathbf{a}-\mathbf{e}$ and $\mathbf{2 a}-\mathbf{e}$ were performed at $2 \mathrm{mM}$ in trifluoroethanol. Solutions with different ratios 1a/ent-1a were obtained from a mixture of stock solutions of $1 \mathrm{a}$ and ent-1a to lead to a final concentration of $2 \mathrm{mM}$ in oligourea. Data were recorded at $20^{\circ} \mathrm{C}$ between wavelengths of 180 and $250 \mathrm{~nm}$ at $0.5 \mathrm{~nm}$ intervals at a speed of $50 \mathrm{~nm} \mathrm{~min}{ }^{-1}$ with an integration time of $2 \mathrm{~s}$.

$\mathrm{X}$-ray Diffraction. Atomic coordinates and structure factors have been deposited in the Cambridge Crystallographic Data Centre with accession codes $1534525,1534527,1534523,1534528$, and 1534526, for structures $\mathbf{1 a}, \mathbf{1 b}, \mathbf{2 a}, \mathbf{1 5}$, and $\mathbf{2 0}$ respectively, and can be obtained free of charge upon request (www.ccdc.cam.ac.uk/data_request/).

\section{ASSOCIATED CONTENT}

\section{Supporting Information}

The Supporting Information is available free of charge on the ACS Publications website at DOI: 10.1021/jacs.7b05802.

Additional experimental procedures and characterization data of all compounds, supplemental Figures S1-S19 and Tables S1-S23 (PDF)

Crystallographic data for 1a (CIF)

Crystallographic data for $\mathbf{1 b}$ (CIF)

Crystallographic data for $\mathbf{2 a}$ (CIF)

Crystallographic data for $\mathbf{1 5}$ (CIF)

Crystallographic data for $\mathbf{2 0}$ (CIF)

\section{AUTHOR INFORMATION}

\section{Corresponding Authors}

*g.guichard@iecb.u-bordeaux.fr

*claudio.palomo@ehu.es

ORCID

Brice Kauffmann: 0000-0002-2932-3255

Gilles Guichard: 0000-0002-2584-7502

\section{Present Address}

"UMR CNRS 8161 Pasteur Institute of Lille, Univ Lille, 1 rue du Pr Calmette, 59021 Lille, France.

\section{Notes}

The authors declare the following competing financial interest(s): D.B., V.D., A.S., L.F., G.G. are co-inventors on a patent application covering oligourea catalysts such as those reported here.

\section{ACKNOWLEDGMENTS}

This work is dedicated to Prof. Dieter Seebach on the occasion of his 80th birthday. The work was funded in part by the CNRS, ANR (ANR-10-PDOC-0022), Conseil Regional d'Aquitaine (Project No. 2014-1R10208), UREkA, and in part by MEC (CTQ2014-62203-EXP, Spain). A predoctoral fellowship from the IDEX of Univ. Bordeaux to D.B. is gratefully acknowledged (funding from the French National Research Agency - Program ANR No. 10-IDEX-03-02). This work has benefited from the facilities and expertise of IECB Biophysical and Structural Chemistry platform (BPCS), CNRS UMS3033, Inserm US001, Univ. Bordeaux.

\section{REFERENCES}

(1) Guichard, G.; Huc, I. Chem. Commun. 2011, 47, 5933-5941.

(2) Checco, J. W.; Gellman, S. H. Curr. Opin. Struct. Biol. 2016, 39, 96-105.

(3) Chandramouli, N.; Ferrand, Y.; Lautrette, G.; Kauffmann, B.; Mackereth, C. D.; Laguerre, M.; Dubreuil, D.; Huc, I. Nat. Chem. 2015, 7, 334-341.

(4) Juwarker, H.; Suk, J. M.; Jeong, K. S. Chem. Soc. Rev. 2009, 38, 3316-3325.

(5) Wang, P. S. P.; Schepartz, A. Chem. Commun. 2016, 52, 74207432.

(6) Horne, W. S. Nat. Chem. 2015, 7, 858-859.

(7) Ringe, D.; Petsko, G. A. Science 2008, 320, 1428-1429. 
(8) Jones, C. R.; Pantos, G. D.; Morrison, A. J.; Smith, M. D. Angew. Chem., Int. Ed. 2009, 48, 7391-7394.

(9) Davie, E. A. C.; Mennen, S. M.; Xu, Y.; Miller, S. J. Chem. Rev. 2007, 107, 5759-5812.

(10) Lewandowski, B.; Wennemers, H. Curr. Opin. Chem. Biol. 2014, 22, 40-46.

(11) Berkessel, A.; Gasch, N.; Glaubitz, K.; Koch, C. Org. Lett. 2001, 3, 3839-3842.

(12) Akagawa, K.; Kudo, K. Angew. Chem., Int. Ed. 2012, 51, 1278612789 .

(13) Burton, A. J.; Thomson, A. R.; Dawson, W. M.; Brady, R. L.; Woolfson, D. N. Nat. Chem. 2016, 8, 837-844.

(14) Coffey, P. E.; Drauz, K.-H.; Roberts, S. M.; Skidmore, J.; Smith, J. A. Chem. Commun. 2001, 2330-2331.

(15) Hasegawa, T.; Furusho, Y.; Katagiri, H.; Yashima, E. Angew. Chem., Int. Ed. 2007, 46, 5885-5888.

(16) Maayan, G.; Ward, M. D.; Kirshenbaum, K. Proc. Natl. Acad. Sci. U. S. A. 2009, 106, 13679-13684.

(17) Müller, M. M.; Windsor, M. A.; Pomerantz, W. C.; Gellman, S. H.; Hilvert, D. Angew. Chem., Int. Ed. 2009, 48, 922-925.

(18) Wang, P. S. P.; Nguyen, J. B.; Schepartz, A. J. Am. Chem. Soc. 2014, 136, 6810-6813.

(19) Le Bailly, B. A. F.; Byrne, L.; Clayden, J. Angew. Chem., Int. Ed. 2016, 55, 2132-2136.

(20) Burgess, K.; Ibarzo, J.; Linthicum, D. S.; Russell, D. H.; Shin, H.; Shitangkoon, A.; Totani, R.; Zhang, A. J. J. Am. Chem. Soc. 1997, 119, $1556-1564$.

(21) Semetey, V.; Rognan, D.; Hemmerlin, C.; Graff, R.; Briand, J.-P.; Marraud, M.; Guichard, G. Angew. Chem., Int. Ed. 2002, 41, 18931895.

(22) Fischer, L.; Guichard, G. Org. Biomol. Chem. 2010, 8, 31013117.

(23) Fremaux, J.; Mauran, L.; Pulka-Ziach, K.; Kauffmann, B.; Odaert, B.; Guichard, G. Angew. Chem., Int. Ed. 2015, 54, 9816-9820.

(24) Collie, G. W.; Pulka-Ziach, K.; Lombardo, C. M.; Fremaux, J.; Rosu, F.; Decossas, M.; Mauran, L.; Lambert, O.; Gabelica, V.; Mackereth, C. D.; Guichard, G. Nat. Chem. 2015, 7, 871-878.

(25) Teyssières, E.; Corre, J.-P.; Antunes, S.; Rougeot, C.; Dugave, C.; Jouvion, G.; Claudon, P.; Mikaty, G.; Douat, C.; Goossens, P. L.; Guichard, G. J. Med. Chem. 2016, 59, 8221-8232.

(26) Collie, G. W.; Bailly, R.; Pulka-Ziach, K.; Lombardo, C. M.; Mauran, L.; Taib-Maamar, N.; Dessolin, J.; Mackereth, C. D.; Guichard, G. J. Am. Chem. Soc. 2017, 139, 6128-6137.

(27) Diemer, V.; Fischer, L.; Kauffmann, B.; Guichard, G. Chem. Eur. J. 2016, 22, 15684-15692.

(28) Wechsel, R.; Raftery, J.; Cavagnat, D.; Guichard, G.; Clayden, J. Angew. Chem., Int. Ed. 2016, 55, 9657-9661.

(29) Zhang, Z.; Schreiner, P. R. Chem. Soc. Rev. 2009, 38, 11871198.

(30) Stone, M. T.; Heemstra, J. M.; Moore, J. S. Acc. Chem. Res. 2006, $39,11-20$.

(31) Doyle, A. G.; Jacobsen, E. N. Chem. Rev. 2007, 107, 5713-5743.

(32) Wenzel, A. G.; Jacobsen, E. N. J. Am. Chem. Soc. 2002, 124, 12964-12965.

(33) Okino, T.; Hoashi, Y.; Takemoto, Y. J. Am. Chem. Soc. 2003, $125,12672-12673$.

(34) Okino, T.; Hoashi, Y.; Furukawa, T.; Xu, X.; Takemoto, Y. J. Am. Chem. Soc. 2005, 127, 119-125.

(35) (a) McCooey, S. H.; Connon, S. J. Angew. Chem., Int. Ed. 2005, 44, 6367-6370. (b) Ye, J.; Dixon, D. J.; Hynes, P. S. Chem. Commun. 2005, 4481-4483. (c) Vakulya, B.; Varga, S.; Csámpai, A.; Soós, T. Org. Lett. 2005, 7, 1967-1969.

(36) Palomo, C.; Oiarbide, M.; Lopez, R. Chem. Soc. Rev. 2009, 38, 632-653.

(37) Probst, N.; Madarász, Á.; Valkonen, A.; Pápai, I.; Rissanen, K.; Neuvonen, A.; Pihko, P. M. Angew. Chem., Int. Ed. 2012, 51, 84958499.
(38) Science of Synthesis: Asymmetric Organocatalysis Vol. 2: Brønsted Base and Acid Catalysts, and Additional Topics; Maruoka, K., Ed.; Thieme Publishing Group: Stuttgart, Germany, 2012.

(39) Kennedy, C. R; Lehnherr, D.; Rajapaksa, N. S.; Ford, D. D.; Park, Y.; Jacobsen, E. N. J. Am. Chem. Soc. 2016, 138, 13525-13528.

(40) Neuvonen, A. J.; Földes, T.; Madarász, Á.; Pápai, I.; Pihko, P. M. ACS Catal. 2017, 7, 3284-3294.

(41) Allen, A. E.; MacMillan, D. W. C. Chem. Sci. 2012, 3, 633-658.

(42) Nelli, Y. R.; Antunes, S.; Salaün, A.; Thinon, E.; Massip, S.; Kauffmann, B.; Douat, C.; Guichard, G. Chem. - Eur. J. 2015, 21, $2870-2880$

(43) Organocatalytic Enantioselective Conjugate Addition Reactions: A Powerful Tool for the Stereocontrolled Synthesis of Complex Molecules; Vicario, J. L., Badia, D., Carrillo, L., Reyes, E., Eds.; The Royal Society of Chemistry: Cambridge, 2010; Vol. 5.

(44) Berner, O. M.; Tedeschi, L.; Enders, D. Eur. J. Org. Chem. 2002, 2002, 1877-1894.

(45) Aitken, L. S.; Arezki, N. R.; Dell'Isola, A.; Cobb, A. J. A. Synthesis 2013, 45, 2627-2648.

(46) Sukhorukov, A. Y.; Sukhanova, A. A.; Zlotin, S. G. Tetrahedron 2016, 72, 6191-6281.

(47) Right-handed $(P)$ foldamers 1a and 2a provided the $(S)$-adduct.

(48) It is noteworthy that the present synergistic catalysis system appears to be more efficient than standard bifunctional Brønsted base/ $\mathrm{H}$-bond catalysts for this particular transformation. See the Supporting Information for details.

(49) Jakab, G.; Tancon, C.; Zhang, Z.; Lippert, K. M.; Schreiner, P. R. Org. Lett. 2012, 14, 1724-1727.

(50) Violette, A.; Lancelot, N.; Poschalko, A.; Piotto, M.; Briand, J. P.; Raya, J.; Elbayed, K.; Bianco, A.; Guichard, G. Chem. - Eur. J. 2008, $14,3874-3882$.

(51) Hemmerlin, C.; Marraud, M.; Rognan, D.; Graff, R.; Semetey, V.; Briand, J.-P.; Guichard, G. Helv. Chim. Acta 2002, 85, 3692-3711.

(52) Lin, B.; Waymouth, R. M. J. Am. Chem. Soc. 2017, 139, 16451652.

(53) Giacalone, F.; Gruttadauria, M.; Agrigento, P.; Noto, R. Chem. Soc. Rev. 2012, 41, 2406-2447.

(54) Quintard, A.; Cheshmedzhieva, D.; Sanchez Duque, M. d. M.; Gaudel-Siri, A.; Naubron, J.-V.; Génisson, Y.; Plaquevent, J.-C.; Bugaut, X.; Rodriguez, J.; Constantieux, T. Chem. - Eur. J. 2015, 21, 778-790.

(55) Pendem, N.; Douat, C.; Claudon, P.; Laguerre, M.; Castano, S.; Desbat, B.; Cavagnat, D.; Ennifar, E.; Kauffmann, B.; Guichard, G. J. Am. Chem. Soc. 2013, 135, 4884-4892.

(56) Zhang, X.; Jones, G. O.; Hedrick, J. L.; Waymouth, R. M. Nat. Chem. 2016, 8, 1047-1053.

(57) Kelly, D. R.; Roberts, S. M. Chem. Commun. 2004, 2018-2020. 